\title{
РОЛЬ ВОКАЛЬНОГО КОМПОНЕНТА В ХОРОВОМ ОБРАЗОВАНИИ
}

\author{
Чжсан Минцзюэ \\ РГПУ им. А. И. Гериена, \\ аспирантка кафедры музыкального воспитания и образования
}

\section{ROLE VOCAL COMPONENT IN CHORAL EDUCATION}

\begin{abstract}
Аннотация. Статья посвящена вопросам специфики вокальной подготовки будущего дирижера-хоровика. Автор обращается к литературе вопроса, выделяя высказывания теоретиков и практиков хорового дирижирования о состоянии вокального образования хоровиков и вокальной работе в хорах. В качестве важнейшего элемента вокального воспитания хоровика предлагается рассматривать тембровый компонент, методами работы с которым богата китайская хоровая культура.

Annotation. The article is devoted to specifics vocal training of a future chorus conductor. Author turns to the literature of the issue, highlighting statements of theorists and practitioners choral conducting about the state vocal education choral singers and vocal work in choirs. It is proposed to consider the timbre component as the most important element vocal education of the chorus, the methods of working with which Chinese choral culture is rich.

Ключевые слова: хоровое дирижирование, вокальная подготовка, певческое дыхание, тембр голоса.

Keywords: choral conducting, vocal training, singing breathing, voice timbre.
\end{abstract}

Профессиональное хоровое образование опирается на такие учебные формы, как хоровой класс, хоровое дирижирование, постановка голоса, хороведение, чтение хоровых партитур, изучение хоровой литературы. Но если работе с хором посвящены ставшие известными классические труды ученых и хоровых мастеров $[1 ; 2 ; 4 ; 6$; 9 и др.], то вокальной подготовке дирижера внимания уделяется значительно меньше. Как правило, это небольшие по объему статьи или методические заметки $[3 ; 5 ; 7 ; 8]$.

Современная проблематика хорового воспитания масштабно освещена в докторской диссертации В.Д. Булгакова «Развитие хорового образования в России во второй половины XIX-XX вв». Автор пишет: «Хоровая культура России имеет богатое педагогическое наследие, которое остается практически неисследованным. Отсутствие работ по педагогическому наследию русской хоровой культуры является серьезным препятствием к созданию научной концепции единого национального музыкально-педагогического процесса» [2, с. 5]. Высказывание ученого универсально, его можно отнести не только к российскому, но и к китайскому хоровому образованию. Обобщая методические и научные труды выдающихся российских хормейстеров, таких как К. Птица, К. Пигров, С. Казачков, А. Анисимов, К. Ольхов, В. Соколов, Г. Дмитревский, В. Булгаков делает неутешительный вывод: научно-практическая деятельность представителей хоровой культуры «...не оказала существенного влияния на практику любительских хоров, состояние которой в 80 -е годы резко ухудшилось в связи с сокращением клубной базы, политической и экономической перестройкой в стране» [2, с. 231]. Это наблюдение ученого также актуально для такой страны, как Китай, в которой хоровое искусство в ХХ столетии играло значительную роль в музыкальной культуре.

Высоко оценивая уровень российской хоровой педагогики, ученый постоянно подчеркивает потенциальную ценность и реальную недостаточность вокального компонента в хоровом образовании, что, по мнению ученого, сказывается на качестве хоровой практики: «Выпускается огромное число специалистов, которые практически не способны научить учащихся элементарному пению» [2, с. 279]. Однако, сам вокальный компонент и его роль в воспитании хорового дирижера не составляет предмета его исследования и не входит в число значимых аспектов концепции диссертации, посвященной преимущественно историческим вопросам хорового образования в России.

Разучивание хорового произведения представляет собой многоуровневый процесс. На начальном этапе осуществляется анализ произведения, осмысление его художественного содержания в тесной связи с эмоциональным впечатлением. Затем начинается усердная работа по освоению музыкального текста, как правило, выстраиваемая от частного к общему: от прорабатывания отдельных деталей к выстраиванию целого. Вокальная сторона хоровой работы присутствует на всем протяжении процесса разучивания, а ее качество максимально выявляет себя в заключительном этапе - исполнении.

На всех этапах хоровой работы присутствуют элементы профессионального вокального тренинга. Хористы должны уметь правильно формировать звук, владеть вокальным звукоизвлечением, проявляющимся в таких его качествах как звонкость, полетность, динамическая гибкость. Кроме того, хоровых певцов следует обучить технике дыхания, правильной атаке звука. Огромное значение имеют также хорошо поставленная артикуляция и дикция. Теоретики и практики хорового дела не раз высказывали мнение о важности вокального компонента в комплексе дисциплин будущего хорового дирижера, поскольку именно руководитель занимается вокальной работой с участниками хорового коллектива $[5 ; 8]$. 
Чтобы научить хористов естественному красивому звукоизвлечению, хоровой дирижер должен сам хорошо владеть основами вокальной работы. Обычно в обучении дирижера акцентируется правильная постановка вокально-речевого аппарата, которая, в свою очередь, опирается на поставленное дыхание.

Организация дыхания представляет собой сложную часть вокально-хоровой работы. Педагоги-вокалисты выделяют грудобрюшное дыхание как основополагающее для пения. Этот вид дыхания высоко ценил выдающийся русский дирижер П. Чесноков [9]. Грудобрюшное дыхание оказывает самое непосредственное воздействие на формирование чистого и красивого звука. При этом певческое дыхание должно находиться в постоянном развитии, которое опирается на правильно подобранный репертуар, на комплекс специальных упражнений, наконец, на регулярный тренинг таких элементов, как вокально-интонационный и тембровый слух.

Точное интонирование представляет собой первостепенную задачу хоровой практики. Фальшивое пение хора неприемлемо и недопустимо. Точность пропеваемых звуков теснейшим образом связана со слухом хористов, и руководители хора не забывают уделять внимание этому компоненту.

Обычно работа над дыханием и интонированием проводится в повседневной хоровой практике распевания. Именно в рамках распевания проводит руководитель вокальную работу с хором. В свою очередь, саму распевку большинство хоровиков строит на основе вокальной методики М.И. Глинки. Обобщая принципы русского композитора, педагог-хоровик И.В. Хвостова в своем докладе «Вокально-хоровая работа в хоровом коллективе как одно из средств интонационной работы» на конференции «Образование и воспитание. Теория и практика» выделяет следующие позиции:

1. Развивать голос следует исходя из примарных, натуральных (или центральных) звуков;

2. Объём, диапазон голоса, в пределах которого можно работать, для слабых певческих мало развитых голосов - всего лишь несколько тонов;

3. Работать надо постепенно, без торопливости;

4. Ни в коем случае нельзя допускать форсирования звучания;

5. Петь следует на умеренном звучании (не громко и не тихо);

6. Наибольшее внимание необходимо уделять качеству звучания и свободе при пении;

7. Большое значение имеет работа над ровностью силы звучания (на одном, на разных звуках, на целой фразе). Эту работу целесообразно проводить в ещё более ограниченном диапазоне;

8. Необходимо уравнивание всех звуков по качеству звучания» [8].

Школа Глинки имеет универсальное значение и до сегодняшних дней используется как в вокальном воспитании будущего дирижера хора, так и в повседневной работе с хором.

Однако, все замечания дирижеров хора о недостаточности вокального образования хормейстера сосредоточены на малом внимании, уделяемом вокальному компоненту в учебном процессе. Авторы детально описывают те элементы вокальной работы, которые следует акцентировать в хоровом образовании. Это будут известные уже принципы работы над дыханием, над артикуляцией и дикцией и, конечно, над постановкой голоса. Петербургский хормейстер В.А. Васильев в статье «О вокальной подготовке хоровых дирижеров» подчеркивает: «...недостаточное внимание к изучению вокального искусства, мастерства, методики постановки голоса и вокальной работы с хором внесло в настоящее время дисбаланс в специальной подготовке хормейстеров» [3, с. 122]. Автор предлагает ввести дисциплину «Постановка голоса и методика обучения пению», подчеркивая, что «...в постановке голоса солиста и певца хора будущего хормейстера почти нет существенных различий...» [3, с. 123]. И все же педагог упоминает о различиях воспитания вокальных навыков у солиста и певца хора. К методическим установкам, предназначенным исключительно для работы с хоровыми певцами, автор относит развитие у всех хоровых певцов диафрагмального дыхания, выработку фальцета у мужских и медиума ${ }^{1}$ у женских голосов [3, с. 125]. Далее автор рассматривает вокальную методику Глинки как опору и основание вокальной работы с хором.

Как видим, целостного описания специфической для хоровиков вокальной работы нет. В основном это выделение общих для солистов и хористов известных принципов с акцентом некоторых упомянутых отличительных особенностей.

Всем, однако, известны положительные и отрицательные характеристики хорового пения. Чистота интонирования, вокальная выразительность представляются качествами самоочевидными, необходимыми «по умолчанию». Высшая похвала хору - «звучит как орган», «богатый тембр», «струнный оркестр». Отрицательные характеристики связаны, как правило, с отсутствием хорового строя или фальшью. Положительные эпитеты подчеркивают важнейшее качество хорового звучания - выстроенность голосов, их слияние в единый полновесный тембр. Именно тембровое единство каждой партии хора, сочетание этих тембровых пластов в гармонии целого составляют высшее достижение хорового пения. А для того, чтобы певцы могли соединить свои индивидуальные вокальные наработки в художественное целое, в единую линию партии, требуется особый вокальный навык, который в работе вокалиста присутствует в наименьшей степени. Ведь если

\footnotetext{
${ }^{1}$ Медиум - микстовое смешение головного и грудного резонаторов
} 
бы недостатки вокального воспитания хоровика сводились к количественным характеристикам (меньше внимания, меньше часов в учебных программах), то хороший хор можно было бы сложить из вокалистов, слегка подучив их хоровой практике, но это не так. Всем известны проблемы вокалистов, попадающих в хор: отсутствие навыка слитности, «микширования» собственного выделяющегося голоса.

Эти качества - способность к слиянию, соинтонированию, к чуткому умножению тембрового аспекта партии - достигаются особыми принципами вокальной работы, которые предполагают овладение навыками тембрового интонирования. Под тембровым интонированием будем понимать максимально свободное владение тембром своего голоса, раскрытие его красочных характеристик, нацеленных на сочетаемость с таким же потенциалом других поющих.

Работа с тембровым аспектом занимала многих выдающихся хормейстеров. Известно, что А.В. Свешников обычно просил певцов: «Пойте с такой силой, чтобы вы могли услышать своего соседа, прислушайтесь к его тембру и подражайте ему» [Цит. по: 5]. Выдающийся деятель русской хоровой культуры ХІХ столетия В.С. Орлов рассматривал хор как своеобразный хоровой оркестр [2, с. 234]. В. Д. Булгаков пишет: «Представив хор как многотембровый оркестр, В. Орлов стремился приблизить детские голоса по звучанию к скрипкам, а мужские - к виолончелям. Хор, по замыслу Орлова, делился на “тяжелую” и “легкую” группу, где каждая партия в свою очередь была поделена на пульты (как в оркестре). В каждый пульт входило 4-5 певцов с голосами, близкими по тембру, благодаря чему дирижер использовал на определенном участке исполнения нужную ему краску, обогащая тем самым палитру звучания хора в целом» [2, с. 234]. Эту регистро-тембровую систему использовали А. Кастальский, В. Булычев, Н. Данилин, А. Никольский, М. Климов, П. Чесноков и другие ученики Синодального училища [6, с. 129]. По мнению исследовательницы К.Ф. НикольскойБерезовской, тембровая трактовка хоровых партий является «открытием, приоритет в которой принадлежит русской школе хорового пения» [там же].

Каковы же факторы, влияющие на развитие тембрового аспекта вокально-хорового интонирования?

Формирование тембра голоса начинается с атаки звука, которая оформляет звук, сообщает ему точную направленность. Поющий хорист в это мгновение уже готов к точному извлечению не только высоты звука, но и его определенной окраски. Атака звука идентична легкому переходу от звука к звуку. Техника атаки звука имеет огромное значение в вокальной работе, поскольку непосредственно связана с освобождением голоса, и, следовательно, с высвобождением природного тембра поющего. Природный певческий тембр существенно отличается от речевого тембра, его главным маркером становится эстетическое качество - красота звучания - и коммуникативность, направленность к слиянию с «тембром соседа».

Самым тесным образом с тембром связаны такие существенные компоненты хорового интонирования как дикция и артикуляция. В практике работы российских хоровых коллективов эти компоненты все же существуют в некоторой ограниченности от вокальной техники в целом и представляют собой специальную область хорового тренинга. Опыт усиленной работы над артикуляцией, достижения ее абсолютной слитности с тембровым качеством певческого звука сокрыт в недрах китайской традиционной вокальной культуры, где одним из умений актерского мастерства в школе пекинской оперы является декламация [10]. Это искусство не идентично театральной декламации в рамках европейского художественного канона. Декламация в пекинской опере представляет собой нечто среднее между выразительным чтением нараспев и вокализированным речитативом. Мастерство декламации ценилось порой выше пения или актерской игры, поскольку в нем задействован красивый тембр голоса и утонченно-эстетизированное произнесение каждого речевого звука. Оно применялось также в качестве хорового комментирования драматических ситуаций, в процессе которого хоркомментатор должен ярко и рельефно описать происходящие события. Разумеется, выразительность коллективного мелодизированного произношения покоится исключительно на сочетании техники артикуляции с тончайшим владением тембровыми контрастами, оттеняющими смысл произносимого.

Стоит также вспомнить актерские амплуа китайского театрального искусства, которые маркированы не только техникой игры определенного персонажа, но и вокально-речевыми характеристиками, основной краской которых является искусно оформленный тембр голоса, «молодой» или «старый», «воинственный» или «кроткий».

Думается, сто из практики китайской традиционной драмы можно внедрить в хоровое образование немало полезных умений и навыков. Анализ этих элементов сквозь призму российской хоровой школы, их преобразование в систему работы над певческим тембром может поспособствовать организации важной части хорового воспитания - вокальной работы над певческим тембром.

\section{Литература:}

1. Асафьев Б.В. О хоровом искусстве: Сб. статей / Сост. и коммент. А. Павлова-Арбенина. - Л.: Музыка, 1980. $-216 \mathrm{c.}$

2. Булгаков В.Д. Развитие хорового образования в России второй половины XIX - XX вв. : дис. ... доктора пед. наук : 13.00.01 / Казань. гос. пед. ун-т. - Казань, 2002. - 355 с. 
3. Васильев В.А. О вокальной подготовке хоровых дирижеров / Труды Санкт-Петербургского государственного института культуры, 2008. Т. 179. - С. 122-135.

4. Иванов-Радкевич А.П. О воспитании дирижера. - Москва : Музыка, 1973. - 75 с.

5. Кузьмийчук Н.А. Основополагающие принципы вокальной методики в хоровом исполнительстве [Электронный pecypc] https://urok.1sept.ru/articles/647539 (дата обращения 16.12.2021). - Режим доступа: открытый.

6. Никольская-Береговская К.Ф. Русская вокально-хоровая школа IX-XX веков: Методическое пособие. M.,1998. - $192 \mathrm{c}$.

7. Стулова Г.П. Хоровой класс : (Теория и практика вокал. работы в дет. хоре) : М. : Просвещение, 1988. 125 с. Хоровой класс - М.: Просвещение, 1988.

8. Хвостова И.В. Вокально-хоровая работа в хоровом коллективе как одно из средств интонационной работы [Электронный pecypc] https://www.predmetnik.ru/conference notes/182 (дата обращения 16.12.2021). Режим доступа: открытый.

9. Чесноков П.Г. Хор и управление им : Пособие для хоровых дирижеров : Москва : Госмузиздат, 1961. $239 \mathrm{c}$.

10. Ли Ган; Ху Шипин. Сборник материалов по исследованиям китайской оперы. Пекин: Морской прилив. 2002. - 612c. (李刚,胡士平《中国歌剧艺术文集》.海潮出版社.2002. - 612页. 